1 Knill-Jones RP, Newman BJ, Spence AA. Anaesthetic practice and pregnancy. Lancet 1975;ii: $807-9$.

2 Whorton D, Krauss RM, Marshall S, Milby TH. Infertility in male pesticide workers. Lancet 1977;ii: 1259-61.

3 Berlin M, Lee IP, Russell LD Effects of metals on male reproduction. In: Clarkson TW, Nordberg GF, Sager PR, eds. Reproductive and developmental toxicity of metals. London: Plenum Press, 1983:29-40.

4 United States Congress Office of Technology Assessment. Reproductive health hazards in the workplace. Washington DC: US Government Printing Office, 1985:4

5 Mettler FA, Moseley RD. Medical effects of ionizing radiation. Orlando: Grune and Stratton, 1985: $159-60$.

6 Sullivan FM, Barlow SM. Congenital malformations and other reproductive hazards from environmental chemicals. Proc $R$ Soc Lond [Biol] 1979;205:91-110.

7 Thomas JA, Brogan WC. Some actions of lead on the sperm and on the male reproductive system. Am $\mathcal{F}$ Ind Med 1983;4:127-34.

8 Tannenbaum TN, Goldberg RJ. Exposure to anaesthetic gases and reproductive outcome. $\mathcal{F}$ Tannenbaum TN, Goldberg
Occup Med 1985;27:659-68.

Miller JF, Williamson E, Glue J, Gordon YB, Grudzinskas JG, Sykes A. Fetal loss after Miller JF, Williamson E, Glue J, Gordon YB, Grudzinsk
implantation-a prospective study. Lancet 1980;ii:554-6.

10 Russell JGB. The rise and fall of the ten-day rule. Br f Radiol 1986;59:3-6.

11 Selevan SG, Lindbohm ML, Hornung RW, Hemminki K. A study of occupational exposure to antineoplastic drugs and fetal loss in nurses. $N$ Engl f Med 1985;313:1173-8.

12 Lee WR. What should we do about work related cancer? Br Med f 1986;292:1155-6.

\section{Man bites dog}

"When a dog bites a man that is not news, but when a man bites a dog that is news" - and recently a man did just that. ${ }^{1}$ But man also seems to be increasingly likely to bite man, and human bites in New York City rank third after dog and cat bites, with an annual incidence of $12 / 100000$ population. ${ }^{2}$ Human bites are potentially more serious than bites from domestic animals, and about three quarters are related to aggressive behaviour (the rest are accidental). Children may be the victims, and bites are often seen on "battered children." ${ }^{3}$ Bites may occur accidentally when people are nursing psychiatrically disturbed patients, and they are an occupational hazard for dentists. They may also occur during sporting or sexual activity.

Two thirds of bites are on the arms, with half of these being on the hands. ${ }^{2}$ Hand bite wounds can be separated into two main types: straightforward bite wounds and the more serious clenched fist injuries that occur when an individual punches another's teeth with a closed fist. The teeth may enter skin and penetrate the extensor tendon, joint capsule, and the metacarpophalangeal joint, damaging the articular surfaces. The patient may well present with what appears to be an innocuous skin wound because the fingers are held in extension-the skin and tendon wounds are thus no longer adjacent and the full extent of the injury is masked. The doctor may miss this injury with disastrous consequences for later hand function. Delay of 12 hours or more in obtaining treatment for penetrating injuries leads to a $60 \%$ complication rate. ${ }^{4}$

Human bites appear to have a greater potential for causing deep necrotising infection than animal bites. ${ }^{5} 6$ The severity may vary with dental hygiene; bacterial counts from even healthy mouths are high, but they have more aerobic flora than mouths of people with poor dental hygiene. Bites from children seem less hazardous-perhaps because they have more aerobic flora. ${ }^{7}$

Goldstein et al looked at 34 patients with human bites, 16 of which were clenched fist injuries. ${ }^{8}$ When first seen all the clenched fist injuries and eight of the 18 simple bites appeared infected: 33 of the 34 patients had aerobic or facultative pathogens isolated, and 18 also had anaerobes. $\alpha$ Haemolytic streptococci followed by coagulase negative staphylococci, Corynebacterium spp, Staphylococcus aureus, and group A streptococci were the most frequent isolates. Bacteroides spp (especially Bacteroides melaninogenicus) were the most common isolated anaerobes. Group A streptococci, $S$ aureus, and Eikenella corrodens were usually associated with infection. Other workers have reported the frequent isolation of penicillin resistant Gram negative organisms, , but Goldstein et al found few.

$S$ aureus has been isolated in up to four fifths of infections caused by human bites in some series ${ }^{10}$ and is often associated with severe infections and complications. ${ }^{4}$ Mann et al found that half of human bites that had a poor outcome had been infected with $S$ aureus. ${ }^{7}$

In one series $E$ corrodens was isolated from $29 \%$ of human bites. ${ }^{11}$ There has been debate over the pathogenicity of this organism in man, but Schmidt and Heckman found that pure infections were associated with long term complications, which they thought supported its pathogenic role. ${ }^{12}$

Syphilis has been reported as being transmitted by a human bite, ${ }^{13}$ and hepatitis $B$ virus may also be transmitted, ${ }^{14-16}$ which is a problem for those caring for the mentally handicapped. Human immunodeficiency virus has been isolated from saliva, ${ }^{17}{ }^{18}$ but there is as yet no substantial evidence to show that it can be spread by biting.

We believe that in managing human bites an aggressive approach is necessary and delay dangerous. Inpatient treatment is usually needed. Generally early exploration of wounds to determine the extent of damage with irrigation and any necessary debridement is important and elevation of the hand helpful. Taylor agrees that only those who present very early with scratches and abrasions can afford to be treated without surgical intervention. ${ }^{19}$ Patients who present without signs of infection with an undetected joint or tendon injury may later develop sesptic complications despite being given what seems adequate antibiotic treatment, which illustrates the importance of wound exploration. Clenched fist injuries must be regarded as infected, and after taking specimens for culture the doctor should start antibiotics immediately. Broad spectrum antibiotics are necessary until the culture and sensitivity reports are available.

Most anaerobic Gram negative rods of the oral flora are penicillin sensitive, and so treatment with penicillin plus a penicillinase resistant penicillin (such as cloxacillin) to cover $S$ aureus is satisfactory. ${ }^{19}{ }^{20}$ Some, however, recommend using flucloxacillin or a cephalosporin alone pending the results of culture. ${ }^{6}{ }^{10}$ Taylor suggested using cephalosporins or erythromycin for patients allergic to penicillin ${ }^{19}$; he did not note any reactions to cephalosporins in his patients. Those who have found a high percentage of Gram negative organisms in human bite wounds recommend using penicillinase resistant penicillin with an aminoglycoside. ${ }^{7}$ Others consider penicillin resistant Gram negative bacilli to be uncommon and treat them only when results of culture are available..$^{20}$ Clostridium tetani is rare in human bites, ${ }^{21}$ but tetanus prophylaxis is provided by many doctors and is still probably desirable. $^{10} 19$

Despite adequate initial treatment complications may still occur. Loss of function, joint stiffness, septic arthritis, osteomyelitis, or tenosynovitis may result from what appeared a trivial injury. Even septicaemia and death, although rare, have occurred. Human bites must never be considered trivial, and accurate diagnosis and treatment must be the aim.

B KIRKPATRICK Registrar in microbiology R WISE

Department of Medical Microbiology,

Consultant and reader

Dudley Road Hospital,

Birmingham B18 7QH 
1 Anonymous. Man bit his dog then set about witnesses. Daily Telegraph 1986;April 4:3.

2 Marr JS, Beck AM, Lugo JA. An epidemiologic study of the human bite. Public Health Rep 1979;94:514-21

3 Rawson RD, Koot A, Martin C, et al. Incidence of bite marks in a selected juvenile population: a preliminary report. F Forensic Sci 1984;29:254-9.

4 Mann RJ, Human bites of the hand. Am Fam Physician 1981;23:110-2.

5 Rest JG, Goldstein EJC. Management of human and animal bite wounds. Emerg Med Clin North Am 1985;3:117-26.

6 Peeples E, Boswick JA, Scott FA. Wounds of the hand contaminated by human or animal saliva. $f$ Trauma 1980;20:283-9.

7 Mann RJ, Hoffeld TA, Farmer CB. Human bites of the hand: twenty years of experience. 7 Hand Surg [Am] 1977;2:97-104

8 Goldstein EJC, Citron DM, Wield B, et al. Bacteriology of human and animal bite wounds. $\mathcal{F}$ Clin Microbiol 1978;8:667-72.

9 Guba AM, Mulliken JB, Hoopes JE. The selection of antibiotics for human bites of the hand. Plast Reconstr Surg 1975;56:538-41.

10 Chuinard RG, D'Ambrosia RD. Human bite infections of the hand. $f$ Bone foint Surg [Am] 1977;59:416-8.

11 Bilos ZJ, Kucharchuk A, Metzger W. Eikenella corrodens in human bites. Clin Orthop 1978;134:320-4.

12 Schmidt DR, Heckman JD. Eikenella corrodens in human bite infections of the hand. $\mathcal{f}$ Trauma 1983;23:478-82.

13 Fiumara NJ, Exner JH. Primary syphilis following a human bite. Sex Transm Dis 1981;8:21-2.

14 Hamilton JD, Larke RPB, Qizilbash A. Transmission of hepatitis B by a human bite: an occupational hazard. Can Med Assoc $\mathcal{F}$ 1976;115:439-40

5 Cancio-Bello TP, de Medina M, Shorey J, Valledor MD, Schiff ER. An institutional outbreak of hepatitis B related to a human biting carrier. F Infect Dis 1982;146:652-6.

16 MacQuarrie MB, Forqhani B, Wolochow DA. Hepatitis B transmitted by a human bite. FAMA 1974;230:723-4.

17 Department of Health and Social Security. Acquired immune deficiency syndrome. Booklet 3. Guidance for surgeons, anaesthetists, dentists and their teams in dealing with patients infected with HTLVIII. London: DHSS, 1986.

18 Schechter MT, Boyko WJ, Douglas B, et al. Can HTLV III be transmitted orally? Lancet $1986 ; 1: 379$.

19 Taylor GA. Management of human bite injuries of the hand Can Med Assoc 7 1985;133:191-2.

20 Goldstein EJC, Caffee HH, Price JE, Citronbaum DM, Miller TA, Finegold SM. Human bite infections. Lancet 1977;ii:1290.

21 Malinowski RW, Strate RG, Perry JF, Fischer RP. The management of human bite injuries of the hand. $\mathcal{F}$ Trauma 1979;19:655-9.

\section{Acyclovir update}

Acyclovir is a potent drug of low toxicity for treating infection with herpes simplex viruses types 1 and 2 and varicella zoster virus, and on occasions its use may be life saving. ${ }^{12}$ The threat of generating resistant strains by widespread, possibly unnecessary, treatment remains, but reports of clinical problems because of resistant strains and of loss of sensitivity during prolonged use of acyclovir are remarkably rare. ${ }^{3}$ This largely theoretical danger should not prohibit using the drug in a patient with important herpes virus infection.

Herpes simplex viruses and varicella zoster virus produce most of their clinical effects by destroying epithelial cells by replicating inside them. Once this damage has been done the healing time in an immunocompetent individual is largely unrelated to the virus. In immunocompromised patients, however, failure to curtail viral replication may lead to prolongation of local lesions and dissemination of infection, which necessitates a different strategy for using acyclovir. Treatment should be considered at any stage of an infection with herpes virus in immunocompromised patients, but in those with normal immune responses clinical benefit is likely only if acyclovir is given soon after the onset of lesions or preferably during the prodromal period. This is illustrated in the trial of oral acyclovir in varicella zoster virus reported by McKendrick et al ( $\mathrm{p}$ 1529). Doctors should not start treatment after uncomplicated infections, minor cold sores, or genital lesions have started and should recognise that these conditions are often past the treatable stage when the patients present.

Recent reports have strengthened the case for using acyclovir in important acute disease caused by herpes simplex viruses. ${ }^{2}$ It helps with herpetic whitlows ${ }^{4}$ and eczema herpeticum, ${ }^{5}$ and the beneficial effects in herpes simplex encephalitis ${ }^{6}$ have now been confirmed. ${ }^{7}$ The recommendations of the authors of the confirmatory study imply that acyclovir should be withheld from patients with herpes simplex encephalitis until a specific diagnosis is made by biopsy of the brain. ${ }^{7}$ Nicholson, however, suggests that treatment should be started at the earliest suggestion of the diagnosis. ${ }^{8}$ In Britain, where herpes simplex virus is the commonest cause of encephalitis, Nicholson's approach seems the most sensible as acyclovir has a low toxicity and occasionally immediate benefit is seen in patients with no localising signs and no abnormalities on the brain scan. Visible lesions may be seen if computed tomography is repeated several days later, and a retrospective serological diagnosis might be made. Craniotomy may be indicated if the patient fails to improve on acyclovir or if focal signs develop.

We are waiting for the results of the analysis carried out by the National Institute of Allergy and Infectious Diseases collaborative antiviral study group of the efficacy of acyclovir in neonatal infection with herpes simplex virus, but the lack of toxicity in neonates means that there is no reason to withhold it. There is no evidence that giving acyclovir to a pregnant woman will protect the offspring from infection, and whether it is safe to do so is not known.

Only those patients most severely affected by varicella should be treated with acyclovir, but successful oral treatment of herpes zoster of the ophthalmic nerve ${ }^{9}$ and other sites (p 1529) suggests that such treatment might eventually be undertaken in general practice-but several points must be remembered. The main objectives of treatment at present are to inhibit the pain that the patient suffers in the acute phase and to prevent the full development of skin lesions; although some of the late ocular complications of ophthalmic herpes zoster are reduced, acyclovir does not reduce the intensity or duration of postherpetic neuralgia. ${ }^{9}$

Low dose acyclovir treatment for herpes simplex virus infections is expensive, and the high oral dose necessary in herpes zoster is likely to increase the cost appreciably. As herpes zoster occurs at some time in about half the population doctors will have to be selective in whom they treat. The drug has to be considered for immunocompromised patients with herpes zoster, but until the efficacy of oral treatment is certain they should continue to receive intravenous acyclovir. Oral treatment for herpes zoster in the immunocompetent should probably be reserved for those who have very early lesions and for those in whom the attack threatens to be widespread or in a critical position, particularly the face. This is easier said than done because predicting the severity of an attack at the time of presentation is very difficult.

D J JEFFRIES

Head of Virology,

Department of Medical Microbiology,

St Mary's Hospital Medical School,

London W2 IPG

1 Timbury MH. Acyclovir. Br Med f 1982;285:1223-4

2 Jeffries DJ. Clinical use of acyclovir. Br Med $\mathcal{J} 1985 ; 290: 177-8$

Barry DW, Nusinoff-Lehrman S, Ellis MN, Biron KK, Furman PA. Viral resistance, clinical experience. Scand $\mathcal{F}$ Infect Dis 1985;47(suppl):155-68.

Laskin OL. Acyclovir and suppression of frequently recurring herpetic whitlow. Ann Intern Med 1985;102:494-5.

Taieb A, Fontan I, Maleville J. Acyclovir therapy for eczema herpeticum in infants. Arch Dermatol $1985 ; 121: 1380$

6 Sköldenberg B, Forsgren M, Alestig K, et al. Acyclovir versus vidarabine in herpes simplex encephalitis. Lancet 1984;ii:707-11.

Whitley RJ, Alford CA, Hirsch MS, et al. Vidarabine versus acyclovir therapy in herpes simplex encephalitis. N Engl f Med 1986;314:144-9.

8 Nicholson KG. Antiviral agents in clinical practice. Lancet 1984;ii:736-8.

9 Cobo LM, Foulks GN, Liesegang T. Oral acyclovir in the treatment of acute herpes zoster ophthalmicus. Ophthalmology 1986;93:763-70. 